\title{
Escola e destinos femininos: São Paulo, 1950/1960
}

\author{
PEROSA, Graziela Serroni. Belo Horizonte: Argvmentvm, \\ 2009. 220p.
}

O livro da professora da Escola de Artes, Ciências e Humanidades da Universidade de São Paulo apresenta uma pesquisa sobre as formas de socialização escolar feminina em famílias de elite na São Paulo dos anos 1950 e 1960 e suas repercussōes nas trajetórias socioprofissionais do grupo em estudo. Foi inicialmente escrito como tese de doutorado, produzida no Grupo de Estudos sobre Instituição Escolar e Organizações Familiares da Faculdade de Educação da Unicamp.

A partir de um estudo do espaço educacional paulista e da conformação de um mercado escolar na passagem do século XIX para o XX, a pesquisadora selecionou três escolas confessionais da cidade, cujas principais características identificou e mapeou, com o intuito de relacioná-las às propriedades sociais de suas ex-alunas. Seu objetivo foi trabalhar a hipótese de que a variação no engajamento profissional dessas mulheres é decorrente da sua experiência escolar, e que esta, por sua vez, é tributária da sua origem social.

A escolha desse período é muito oportuna, na medida em que situa o momento histórico em que se amplia o acesso feminino ao ensino superior. Conhecer como a possibilidade de profissionalização feminina se configura nesse período e seus desdobramentos nas camadas sociais privilegiadas não é tarefa simples, pois, como bem aponta a autora, reportando-se a Bourdieu, as mulheres de elite são uma fração dominada de um "grupo social dominante". Embora estejam numa posição de dominação devido à classe social a que pertencem, têm a sua socialização definida pela preparação para uma posição dominada na família.

Apontando três configurações de colégios, uma "mais austera", uma "mais moderna" e uma "clássica", Graziela Perosa mostra, em primeiro lugar, que as * Professora do Setor de Orientação Educacional do Colégio de Aplicação da Universidade Federal
do Rio de Janeiro, Brasil. glaucia.3m@cap.ufrj.br 
diferenças entre eles correspondem a diferenças entre as famílias e, mais do que isso, que o estilo educativo de cada um está perfeitamente sintonizado com as expectativas das famílias a que atende. Isso é tomado como indício do quanto essas famílias de grupos dominantes têm o poder material e simbólico de controlar a educação que desejam para suas filhas, de forma que a experiência escolar dê continuidade e reforço à educação recebida em casa e contribua para construir as trajetórias sociais possíveis e desejadas por essas famílias para suas filhas. A autora utiliza a noção de "educação total" para compreender esse ajustamento entre escolas e famílias, mostrando seus efeitos, inclusive sobre as disposições psíquicas que vão guiar as escolhas pessoais e profissionais das exalunas desses colégios.

O livro está organizado em quatro capítulos. No primeiro, é apresentada uma ampla pesquisa sobre as transformaçōes no espaço educacional paulistano. O estudo sobre as relações de concorrência existentes entre as escolas, sobre as estratégias de cooptação de alunos, assim como o acompanhamento das mudanças de endereço das famílias de alta renda e dos colégios, favorece a compreensão do processo de diferenciação social baseada na escolarização e no status profissional que aconteceu na São Paulo do início do século XX, captando o dinamismo da capital paulista, frequentemente modificada por fluxos migratórios, flutuações socioeconômicas e políticas, bem como pelas intensas transformaçōes urbanas ocorridas no período.

No segundo capítulo, são apresentados os colégios selecionados para o estudo: três escolas femininas, fundadas a partir de 1907, com intervalos de vinte anos entre cada uma delas. Enfrentando com habilidade a noção de "escola para meninas", a autora demonstra as diferenças e as oposiçóes que se ocultam sob esse rótulo, revelando as fraturas e a heterogeneidade presente no interior do grupo dominante que frequentava esses colégios.

A diferenciação entre as escolas é demonstrada pelo estudo da vinda das respectivas ordens religiosas para o Brasil; da forma de inserção de cada um dos colégios na cidade; da localização do estabelecimento, da arquitetura dos prédios e da hierarquia dos bairros em questão, bem como da origem social e da qualificação educacional das religiosas e do tipo de socialização realizado nas instituiçōes.

A observação de características da socialização escolar, tais como as metodologias de ensino, o uso e o controle dos uniformes, as estratégias de aprendizagem dos códigos de "boa conduta" e tantos outros aspectos contemplados na pesquisa de Perosa apoiam e dão substância à hipótese da diferenciação entre as instituiçôes. Nesse sentido, a inclusão de material iconográfico nas fontes de pesquisa, aliada à maneira com que este foi analisado e interpretado, sublinhando-se desde detalhes da disposição dos móveis e objetos até a 
forma de vestir e os usos do corpo, contribuiu para explicitar o "espírito" de cada um dos colégios.

Já o terceiro capítulo apresenta a caracterização da posição social das famílias em suas fronteiras e articulações. Utilizando os dados de um questionário respondido por ex-alunas dos colégios, a autora incorpora informaçóes sobre a atividade econômica, a qualificação educacional e a participação política dos avós; sobre a área construída das residências, o número de empregados domésticos, os hábitos da família durante as refeições, a familiaridade no uso de transportes coletivos e tantos outros aspectos que contribuem para ampliar a compreensão das dimensões do patrimônio e do capital dessas famílias.

O quarto e último capítulo trabalha, fundamentalmente, com a análise das trajetórias socioprofissionais das ex-alunas. A reflexão empreendida pela autora é direcionada para a compreensão da articulação entre o duplo pertencimento social - de gênero e de classe - no grupo em estudo. As principais variáveis consideradas nessa etapa do trabalho foram o grau de escolaridade das ex-alunas e de suas mães, as áreas e as instituições escolhidas na graduação superior, o engajamento e a longevidade de atividade profissional, as alianças matrimoniais, as taxas de fecundidade nas duas últimas geraçóes, a escolaridade e a ocupação do cônjuge.

Com o objetivo de melhor entender as trajetórias sociais do grupo de exalunas das três escolas, a autora faz uso da técnica de análise fatorial, também utilizada no estudo sobre o espaço educacional paulista, apresentado no início do livro. A análise comparativa sistemática propiciada por essa técnica gerou uma elucidativa visualização do posicionamento social das alunas em relação às trajetórias sociais possíveis, explicitando oposiçōes, distâncias e proximidades e relacionando-as à origem social e às experiências de escolarização a que estiveram expostas. É a partir dessa análise fatorial que foi realizada a seleção das exalunas a serem entrevistadas e foram construídos quatro casos exemplares que ilustram trajetórias desse grupo.

Ainda na perspectiva metodológica, cabe ressaltar a riqueza das fontes utilizadas, o diferencial na construção das categorias e a submissão dos dados a técnicas analíticas diversas. A cada capítulo Graziela Perosa apresenta e descreve precisamente as etapas de constituição da pesquisa, dando a conhecer aos leitores suas hipóteses e opções metodológicas, a importância de cada uma das fontes para a análise e para o trabalho como um todo. Dessa forma, envolve o leitor e, ao mesmo tempo, torna seu livro um guia prático para pesquisadores da área.

$\mathrm{Na}$ medida em que os dados obtidos por questionário fortalecem bastante a argumentação, deveria considerar-se a possibilidade de homogeneizar sua apresentação numa segunda edição do livro, já que sua discussão se ressente do fato 
de a autora não ter elegido uma forma constante de apresentá-los, referindo-se a eles ora em termos percentuais, ora como fraçóes e, mesmo, em alguns momentos, em termos absolutos, sem relacionar as cifras ao total de respondentes. Algumas tabelas também apresentam totais que não correspondem ao número de respondentes declarados.

Diversas linhas de estudo buscam contribuir para a compreensão das influências da escola nas trajetórias de vida de seus estudantes e grande parte desses estudos focaliza seu desempenho cognitivo e acadêmico. A pesquisa de Graziela Perosa aborda a temática sob perspectiva diferente, incorporando, desde sua concepção, a dimensão sócio-histórica das interaçôes entre diversas esferas sociais que constroem e determinam os diferentes perfis das instituições escolares estudadas.

Em sua análise, Perosa relaciona a circunscrição das atividades profissionais das ex-alunas a um universo profissional estritamente feminino, ao intenso e prolongado contato com a moral católica que vigorava tanto nos colégios como nas famílias. Da mesma forma, correlaciona as três modalidades profissionais prevalentes, em cada um dos três grupos de alunas, às alianças matrimoniais que acabam por estimular ou desencorajar os investimentos em determinadas modalidades profissionais. Escola e destinos femininos é uma leitura que nos permite melhor compreender os dilemas da profissionalização das mulheres brasileiras nesse período histórico do país e, ao mesmo tempo, estimula o investimento na ampliação de estudos, sob a mesma perspectiva teórica, que incorporem outros estratos sociais, vinculados a estilos outros de instituições educacionais. 